\title{
Equality on the Bus: Case Comment on Paulley v FirstGroup PIc
}

\author{
Akeel Tariq, University of Huddersfield
}

\section{akeel.t@hotmail.co.uk}

Accepted date: 09/11/2017

Published date: 21/02/2018

\begin{abstract}
The Equality Act 2010 imposes a duty on employers and organisations to make sure that disabled people have easy access to education, jobs and services. This ensures that they are treated equally with non-disabled people.

Over the years, employers have been looked down upon for failing to make reasonable adjustments for disabled people by both the EHRC and judges. There seems to be much more focus on how and why employers should treat disabled people equally, leaving organisations and service providers behind. As a result, there has not been much deliberation on how far service providers should go when making reasonable adjustments for disabled people.
\end{abstract}

Paulley $v$ FirstGroup $P / c^{1}$ is the first case of its kind to discuss the duty upon service providers to make reasonable adjustments to their services for disabled people. It has therefore been quite a contentious case, attracting mixed opinions from academics and disability and equality supporters. This article sets out the key facts of the case, followed by the judge's reasoning, judgment and analysis. Essentially, the main question the decision in this case raises is whether it has struck a balance

\footnotetext{
1 Paulley v FirstGroup PIc [2017] UKSC 4 [2017] 1 WLR 423 (SC)
} 
between disabled people's rights to freedom from discrimination and the reasonable adjustments that service providers are required to make.

\section{Keywords}

Discrimination, Paulley, FirstBus, disability, freedom, reasonable adjustments, service providers 


\section{Background}

Mr Doug Paulley, a disabled man, appealed against a decision that the defendant, FirstGroup Plc, did not discriminate against him in relation to his disability.

FirstGroup Plc's company policy at the time stated that when a non-wheelchair user refuses to vacate the space at the bus driver's request, nothing else would be done to ensure that the space is free. The appellant, Mr Paulley, was not allowed to board a FirstGroup bus. This was because the wheelchair space was already occupied by a woman with a child in a pram, who refused to move at the bus driver's request. There was a notice above the wheelchair space that read, 'Please give up this space for a wheelchair user'. The bus driver also refused to allow Mr Paulley to fold his wheelchair and use an ordinary seat on the bus due to health and safety reasons. Subsequently, Mr Paulley was not allowed to board the bus and missed his train. ${ }^{2}$

\section{Legal provisions}

The Supreme Court had to decide whether FirstGroup Plc had, indeed, failed to perform its duty under s.29(7) and s.20(3) of the Equality Act 2010. S.29(7) holds that a service provider must make reasonable adjustments to make sure that they do not discriminate against anyone who is in need of their service, by refusing to provide them with the service ${ }^{3}$ while s.20(3) states that 'where a provision, criterion or practice of A's puts a disabled person at a substantial disadvantage in relation to a relevant matter in comparison with persons who are not disabled, [the service provider has a duty] to take such steps as it is reasonable to have to take to avoid the disadvantage'. ${ }^{4}$ Mr Paulley claimed that the reasonable adjustments that

\footnotetext{
2 ibid

${ }^{3}$ Equality Act 2010, s 29(7)

${ }^{4}$ Equality Act 2010, s 20(3)
} 
FirstGroup Plc should have made to its policy were to bind the bus driver with the duty of pressurising the non-wheelchair user to vacate the space, upon refusal.

\section{Judgment}

The Supreme Court allowed Mr Paulley's appeal. The court held that FirstGroup Plc's policy of simply just asking a non-wheelchair user to vacate the space without taking any further steps was unfair. The judge admitted that it would be unreasonable to have an absolute rule that non-wheelchair users had to vacate the space immediately. ${ }^{5}$ However, he stated:

When such a refusal is unreasonable and there is some other place on the bus to which such a passenger could move, there is no reason why the driver should not be expected to rephrase any polite request as a more forceful requirement to move, and if that does not work and especially if the bus is ahead of schedule, why the driver should not be expected to consider whether there was any reason why the bus should not stop for a few minutes with a view to pressurising or shaming the recalcitrant non-wheelchair user to move. ${ }^{6}$

In coming to his conclusion, Lord Neuberger followed the reasoning of Baroness Hale in Aster Communities Ltd v Akerman-Livingstone that 'treating a man equally with a woman usually means treating him in the same way as a woman is treated ... however ... treating a disabled person equally with a non-disabled person may mean treating him differently from a non-disabled person'. ${ }^{7}$ This suggests that it is

\footnotetext{
${ }^{5}$ Paulley v FirstGroup PIc [2017] UKSC 4 [2017] 1 WLR 423 (SC) (Lord Neuberger of Abbotsbury PSC) ${ }^{6}$ ibid

${ }^{7}$ Aster Communities Ltd (formerly Flourish Homes Ltd) v Akerman-Livingstone (Equality and Human Rights Commission intervening) [2015] UKSC 15 [2015] AC 1399 (Baroness Hale of Richmond DPSC) [2]
} 
acceptable to give preferential treatment to disabled people, but not to women.

'Whilst the decisions of the members of the Supreme Court differ, at the very least, bus companies can be expected to ensure that their drivers go as far as appropriate in the circumstances to induce a recalcitrant passenger to reconsider an initial refusal. ${ }^{\prime 8}$

\section{Analysis}

The characterisation of this as the 'wheelchair -v-buggy' case has been unhelpful. Many wheelchair users make use of public transport on a daily basis without issue. As noted in the judgment of the Supreme Court, Mr Paulley was a frequent user of public transport and this was the first time that he was unable to get on a bus because someone refused to vacate the space. There are not daily battles between wheelchair users and parents with young children. The opening paragraph of the Court of Appeal's judgment made it clear that common decency and respect for wheelchair users should mean that other passengers make way for them where possible. Such decency largely prevails on the public transport system. Attempts to characterise this as a battle between these different groups is likely to cause the erosion of such decency and potentially lead to confrontation, something that should be avoided at all costs. ${ }^{9}$

This suggests that in attempting to provide disabled people with justice, the case may become a cause of conflict between disabled people and non-disabled people.

\footnotetext{
${ }^{8}$ Robin Allen and Catherine Casserley, 'Supreme Court hands down landmark disability decision in Paulley v FirstGroup plc' (Cloisters News, 18 Jan 2017) http://www.cloisters.com/latest/supreme-court-hands-downlandmark-decision-in-paulley-v-firstgroup-plc accessed 1 September 2017

${ }^{9}$ Steven Flynn, 'Supreme Court hands down judgment in "Wheelchair - v- Buggy" dispute' (2017) http://stjohnsbuildings.com/wp-content/uploads/Steven-Flynn-Comment-on-Paulley.pdf accessed 1 
As a result, people will focus on the difference between them and disabled people. This, in turn, would defeat the purpose of the Equality Act 2010.

Moving on, academics have expressly stated that the decision in Paulley $v$ FirstGroup Plc 'may be of wider application than simply bus operators'. ${ }^{10}$ Various transport and service providers, such as train companies, have been advised to 'review their policies to consider whether they are taking sufficient steps to require non-wheelchair users to cede designated wheelchair spaces to wheelchair users'.11 However, it could be argued that new training could be quite expensive and difficult to implement, thus suggesting that there is not much that employees of public service providers can do to avoid discriminating against disabled people when nondisabled people refuse to vacate a designated disabled space. ${ }^{12}$ Also, although service providers are under a duty to make reasonable adjustments for disabled people, 'they also owe a duty of care to their employees'. ${ }^{13}$

'Requiring drivers to confront unreasonable passengers may result in drivers being injured; thereby giving rise to claims for personal injury against the transport company. ${ }^{14}$ This would not help the current rise in personal injury claims in general. For example, personal injury claims for road traffic accidents in particular have risen in recent years. 'According to the Government's Compensation Recovery Unit,

\footnotetext{
${ }^{10}$ Practical Law Journal, 'Disability discrimination: Supreme Court considers reasonable adjustments under Equality Act 2010’ IDS Emp L Brief 20171065 3-5

11 ibid

12 ibid; see also Jenny White, 'Disability discrimination and the travel industry: an outline of the law' [2004] ITLJ 3 135-139

${ }^{13}$ Steven Flynn, 'Supreme Court hands down judgment in "Wheelchair - v - Buggy" dispute' (2017) http://stjohnsbuildings.com/wp-content/uploads/Steven-Flynn-Comment-on-Paulley.pdf accessed 1 September 2017 14 ibid
} 
personal injury claims rose by about 50pc to 773,000 a year between 2007 and 2014, at a time when accidents reported to the police fell $23 p c .^{\prime 15}$ Furthermore, Lord Neuberger recognised that the temperaments and experiences of different drivers are bound to vary; some will handle the situation well and others will find it difficult to cope. Those who find it difficult to cope may suffer work related stress if they are required to confront a passenger who reacts in a hostile manner. Similarly, they are likely to be caused stress if they refuse to continue the journey until the offending passenger moves. This is likely to bring the driver into conflict with other passengers and, if stationary on a busy high street in rush hour, with other road users. ${ }^{16}$

Nevertheless, it is argued that 'where a driver who has made such a request concludes that such a refusal is unreasonable, he or she should consider some further step to pressurise the non-wheelchair user to vacate the space, depending on the circumstances'. ${ }^{17}$ Underhill LJ reiterated this in the Court of Appeal judgment, stating that he would

hope and expect that, other things being equal, a driver whose first request to a non-wheelchair user to vacate the wheelchair space was refused would not simply shrug his or her shoulders and go back to the cab, and that there would normally be some attempt at further persuasion or pressure (possibly

\footnotetext{
${ }^{15}$ Marion Dakers, 'Stubbornly high personal injury claims set to push up cost of car insurance' The Telegraph (15 June 2015)

${ }^{16}$ Steven Flynn, 'Supreme Court hands down judgment in "Wheelchair - v - Buggy" dispute' (2017) http://stjohnsbuildings.com/wp-content/uploads/Steven-Flynn-Comment-on-Paulley.pdf accessed 1 September 2017

${ }^{17}$ Richard Hartley, 'Wheelchairs reign supreme in battle against prams (kind of)' Metro (18 January 2017) http://metro.co.uk/2017/01/18/battle-between-prams-and-wheelchairs-on-buses-to-be-resolved-6387943/ accessed 18 January 2017
} 
even including a threat not to proceed with the journey until the space is cleared-though this risks seriously inconveniencing other passengers). ${ }^{18}$

Catherine Casserley and Sally Robertson have further expressed that not only bus providers, but other service providers,

will need to revisit their policies to ensure that they advise drivers of the steps that they need to take if the space is occupied. They will need to do more than simply ask someone to move from the space; they will need to pressurise them to do so, ideally by saying that they are required to move. And if that person does not, then they may need to stop the bus from moving on to give that person time to move. Assistance with, for example, folding the pushchair may also need to be given. New policies will also require training. ${ }^{19}$

How practical this would be is a cause for concern, in terms of deciding how much the bus driver could possibly do. Pressurising pushchair users to vacate the space could inevitably cause further legal action to be taken against FirstGroup Plc. Also, despite Underhill LJ's view that bus drivers should do more than merely request nonwheelchair passengers to move, he went on to express that he 'would be very uneasy about concluding that a bus company was in breach of its duty under section 20(3) of the Act unless it had a policy that positively required drivers to reinforce the basic request by one or more of those means'. ${ }^{20}$ Although the Court of Appeal judgment was subsequently overruled, Lord Lewison shared similar views to Underhill LJ in the Supreme Court judgment.

\footnotetext{
18 Paulley v FirstGroup PIc [2014] EWCA Civ 1573 [2015] 1 W.LR 3384 (Underhill LJ) [68]

${ }^{19}$ Catherine Casserley and Jane Robertson, 'Paulley: An everyday step' (Cloisters, 30 Jan 2017) http://www.cloisters.com/blogs/paulley-an-everyday-step accessed 29 August 2017

20 ibid 18
} 
Lord Lewison, dissenting, believed that the decision was 'a step too far' and that FirstGroup Plc's policy did not breach the Equality Act 2010. He further accepted that although disabled people should have a right to expect reasonable adjustments from service providers, it would be unreasonable for bus drivers to forcibly remove passengers from the bus. ${ }^{21}$ This raises issues about the amount of force bus drivers are expected to use in such cases. How much force is reasonable before it turns into an offence of battery? Also, one cannot expect a bus driver to sue a non-wheelchair passenger for refusing to move, ${ }^{22}$ thus suggesting that there is a lack of clarity in the decision.

Furthermore, some academics have argued that the Supreme Court's decision looked at wheelchair users as a whole, rather than the individual disabled person. This affected the court's decision a lot, as if the decision was based solely on $\mathrm{Mr}$ Paulley, it most likely would have been different. For example, in a similar case, Black v Arriva North East Ltd, the County Court held that the service provider was not in breach of the reasonable adjustment duty for allowing pushchair users to use the wheelchair space on a bus on a first come, first served basis. ${ }^{23}$ The reasoning behind this decision was that the wheelchair user was not at a substantial disadvantage for having to wait for another bus.

However, it has been argued that the decision was wrong and unfair as the court failed to consider Schedule 2 of the Equality Act, and so looked at the individual disabled person rather wheelchair users as a group. By

\footnotetext{
${ }^{21}$ Paulley v FirstGroup plc [2017] UKSC 4 [2017] 1 WLR 423 (SC) (Lord Lewison) [50]; see also Jan Miller, 'Rights on the buses' 164 NL 7634 p5 (1); Nigel Powell, 'Challenging service providers to make reasonable adjustments' [2009] EOR 2009187 25-27

22 ibid

${ }^{23}$ Black v Arriva North East Ltd [2013] Eq LR 558 (CC)
} 
contrast, in the Paulley case it was held there was a substantial disadvantage - and that the bus company had not taken reasonable steps. There may be differences due to the facts of an individual case, but clearly the Paulley case should be followed as regards the law, rather than Black, since the latter was only a County Court decision. ${ }^{24}$

However, the Supreme Court did not go as far as Mr Paulley and some disability rights organisations had hoped. Rather than provide certainty as to the extent of service providers obligations, the decision has left both wheelchair users and transport companies unsure as to exactly what is required in order to comply with the duty to make reasonable adjustments. ${ }^{25}$

Also, where disability and equality supporters have expressed acceptance of the decision, they have also noted that the Supreme Court's decision could have gone a step further. This is because the decision does not rectify the discrimination, 'created by the policies of FirstGroup, and likely the policies of countless other companies around the country'. ${ }^{26}$ Furthermore, Lord Toulson commented that this is an area of law that may require legislative consideration, as the Supreme Court's decision is nowhere near being straightforward. ${ }^{27}$ Ideally, the decision should have required FirstGroup Plc to implement training for their staff with immediate effect. Surely this would give some peace of mind not only to people with physical disabilities, such as wheelchair users, but also to people with mental disabilities. Had the decision

\footnotetext{
${ }^{24}$ Paulley v First Group PIc, http://www.stammeringlaw.org.uk/cases/paulley.htm accessed 1 September 2017 ${ }^{25}$ Steven Flynn, 'Supreme Court hands down judgment in "Wheelchair - v - Buggy" dispute' (2017) http://stjohnsbuildings.com/wp-content/uploads/Steven-Flynn-Comment-on-Paulley.pdf accessed 1 September 2017

${ }^{26}$ Jodee Mayer, 'Is the judgment in Paulley v FirstGroup actually a victory for wheelchair users?' (2017) https://www.boltburdonkemp.co.uk/news-blogs/spinal-injury-blogs/judgment-paulley-v-firstgroup-actuallyvictory-wheelchair-users/ accessed 15 January 2018

27 Paulley v FirstGroup plc [2017] UKSC 4 [2017] 1 WLR 423 (SC) (Lord Toulson JJSC)
} 
required FirstGroup Plc to make changes, it would have given disabled people the reassurance that justice has, indeed, been served.

Jodee Mayer further states that the Supreme Court let the opportunity to create new legislation go. This could have helped to correct the mischief in this area of law and, as a result, reduced the amount of inequality disabled people face daily. 'Therefore...we are not much, if any, further forward in creating equality for people with disabilities as a result of this judgment. ${ }^{28}$ Another interesting point that was not fully considered in the judgment is that 'a requirement that the person occupying the wheelchair space be asked to leave it or the bus, might arguably indirectly discriminate against women who need the space to convey small children' ${ }^{29}$ This would then clearly contradict the reasoning behind the judgment, which was to give protection to Mr Paulley from discrimination.

Despite the amount of criticism the decision in Paulley $v$ FirstGroup Plc ${ }^{30}$ has received, Richard Griffith has suggested that in light of the decision, the public is in a good position to persuade the Department for Transport to amend their public service transport conduct regulations, following their consultation issued in $2014 .{ }^{31}$ Nevertheless, this is highly unlikely to occur, as 'the department has made it clear they are not open to requests to increase regulation in relation to conduct on buses. The decision of the Court of Appeal will therefore stand until a further appeal by the UK Supreme Court is heard. ${ }^{32}$ Another possible recommendation following the Supreme Court's decision is to enhance the inclusive design of buses, as 'there was

\footnotetext{
28 ibid 26

${ }^{29}$ Spencer Keen, 'Room to manoeuvre?' [2017] 167 NLJ 7734, p11

30 Paulley v FirstGroup plc [2017] UKSC 4 [2017] 1 WLR 423 (SC)

${ }^{31}$ Richard Griffith, 'Pushchairs can occupy wheelchair spaces on buses' British Journal of Midwifery [2015] Volume 23 Issue 2

32 ibid
} 
only one designated wheelchair space on the bus. 'Not only does this make it impossible for two people to travel together if they both happen to be wheelchair users, but it also intensifies the demand for that space by passengers who have buggies, luggage or dogs.' 33

On the other hand, support for the decision in Paulley $v$ FirstGroup Plc ${ }^{34}$ is given by Lady Hale in the judgment itself. She identifies that while the ability to travel is important to all of us, it is of higher importance to disabled people. This is because 'without the ability to travel they risk becoming socially isolated and losing confidence in themselves'. ${ }^{35}$ Considering that there are 12 million disabled people in the United Kingdom, of whom 2 million are wheelchair users, it is clear that there must be provisions in place to help them to travel to work, without being discriminated against. ${ }^{36}$ This is especially the case when the number of disabled people going to work is increasing, as they are given more rights to work and live independently today under the UN Convention on the Rights of Persons with Disabilities 2006, as opposed to, say, 10 years ago. ${ }^{37}$ The purpose of this convention has been described as 'aiming ... to ensure that all existing rights are actually enjoyed in practice by all disabled people on an equal basis with others'. ${ }^{38}$ This is exactly what the decision in Paulley v FirstGroup P/c ${ }^{39}$ does. Also, 'given successive governments' failures to

\footnotetext{
${ }^{33}$ Anna Lawson and Catherine Casserley, 'FirstGroup v Paulley: Towards Accessible and Inclusive Public Transport?' (Oxford Human Rights Hub, 3 March 2017) http://ohrh.law.ox.ac.uk/first-group-v-paulley-towardsaccessible-and-inclusive-public-transport/ accessed 23 March 2017

34 Paulley v FirstGroup plc [2017] UKSC 4 [2017] 1 WLR 423 (SC)

35 Paulley v FirstGroup plc [2017] UKSC 4 [2017] 1 WLR 423 (SC) (Baroness Hale of Richmond DPSC) [93]

${ }^{36}$ Papworth Trust, 'Disability in the United Kingdom 2014, Facts and figures' (2014) http://www.papworthtrust.org.uk/sites/default/files/UK\%20Disability\%20facts\%20and\%20figures\%20report\% 202014.pdf accessed 23 March 2017

37 Brian Doyle, 'Disabled Workers' Rights, the Disability Discrimination Act and the UN Standard Rules' [1996] Ind Law J (1996) 25 (1) 1-14; see also Phillip Leith, 'Merit, Speech Disability and Discrimination' [2014] 20(3) Web JCLI

${ }^{38}$ Tabitha Collingbourne, 'The Care Act 2014: a missed opportunity?' [2014] 20(3) Web JCLI

39 Paulley v FirstGroup plc [2017] UKSC 4 [2017] 1 WLR 423 (SC)
} 
remove or mitigate barriers to travel faced by disabled people daily, Paulley can only be of help'. ${ }^{40}$ Furthermore,

the Disability Rights Commission has identified this lack of cases as an area of real concern. The law against disability discrimination is only going to work if service providers and education providers feel there is a real threat of sanction. Until more cases come to court, the law will not be seen to be working. ${ }^{41}$

This is especially the case since 'consumers rarely articulate their complaint as "discrimination" - or invoke the Equality Act. More often than not, they're simply frustrated at being unable to access the services they want or need to - and feel that the business's processes are unnecessarily inflexible and impersonal.' ${ }^{42}$ Although $\mathrm{Mr}$ Paulley did not receive any compensation for discrimination, the fact that this case went all the way to the Supreme Court, and was heard by seven justices rather than the normal five, indicates a victory for disabled people. This case could put pressure on service providers to provide training for their staff, as well as take disability discrimination more seriously, which is a victory in itself for Mr Paulley.

Moreover, David Isaac labelled the decision as 'a victory for disabled people's rights' and 'a hugely important decision, which has helped clarify the current state of the law, and will give confidence to thousands of disabled people in Britain to use public

\footnotetext{
${ }^{40}$ Catherine Casserley, Jane Robertson, 'Paulley: An everyday step' (Cloisters, 30 January 2017) http://www.cloisters.com/blogs/paulley-an-everyday-step accessed 29 August 2017

${ }^{41}$ Irene Henrey, 'Disabled from suing?' (2007) http://www.journalonline.co.uk/Magazine/52-2/1003859.aspx accessed 30 August 2017

42 'Making reasonable adjustments - and meeting particular needs' Ombudsman News (January/February 2015)
} 
transport'. ${ }^{43}$ Consequently, Mr Paulley's success in this case will potentially make life easier for wheelchair users wanting to use public transport who have been reluctant to use it in the past, due to the 'first come, first served' policies. The decision has, 'corrected ... a confusing policy which has caused untold problems for disabled people'. ${ }^{44}$ In addition, the Supreme Court's ruling on the case has been said to have provided a balance between the practicality of the situation and the law. Jan Miller submits that the decision has clarified that bus drivers must request a nonwheelchair user to move, if they refuse; and, 'if they think the person occupying the space is being unreasonable, they can rephrase the request as a requirement and then stop the bus for a few minutes to pressurise the person to move'. ${ }^{45}$ This view is also supported by other academics who state that the decision is correct, as FirstGroup Plc's policy, 'constituted unjustified discrimination and was ... unlawful'. ${ }^{46}$ It could also be argued that education and employment providers already have various guidance documents in place for disabled people, whereas service providers have to wait for a case like Mr Paulley's to go all the way to the Supreme Court before they take some action.

The duty in relation to service provision is slightly different from the employment duty in that it is 'anticipatory' in nature. This means that service providers have to think in advance about what changes may be needed to

\footnotetext{
${ }^{43}$ Equality and Human Rights Commission, 'Wheelchair spaces on buses must be a priority, court rules' Equality and Human Rights Commission (18 January 2017) https://www.equalityhumanrights.com/en/ourwork/news/wheelchair-spaces-buses-must-be-priority-court-rules accessed 23 March 2017 44 ibid

45 Jan Miller, 'Bus decision struck "balance”' [2017] 167 NLJ 7731 p5 (3); see also Sue Highmore, 'The Equality Act - its effect on property owners and tenants: Part 1' [2010] L \& T Review 2010 14(4) 134-137

46 Public Law, 'Discrimination' [2017] PL 2017 Apr 298-301; see also Keystone Law, 'Disability discrimination: reasonable adjustments' [2017] PLC 2017 28(2) 67-68; Peter JG Williams and Richard Waugh, 'On the wrong track' [2005] EG 20050517117
} 
their services to facilitate disabled users, rather than just waiting until a disabled customer approaches them. ${ }^{47}$

This has been reiterated by Irene Henrey: 'It should be noted that the duty to make reasonable adjustments is a duty to disabled people at large, regardless of whether the service provider knows that someone is disabled. It is an anticipatory duty and requires the service provider to plan ahead.' ${ }^{48}$ Although 'many service providers have already made changes to their services to accommodate disabled people such as putting in ramps or providing information in large print, or in braille', ${ }^{49}$ they should do much more. In addition, it has been expressed that the Supreme Court's decision

is likely to have wider implications for the public transport industry beyond Bus Operators, and in particular Train and Tram Operators will need to review the decision carefully. However, the implications may also extend to disabled access and seating in public areas generally, and could go so far as to affect shops, restaurants, theatres, libraries and providers of other shared public facilities. ${ }^{50}$

This further suggests that the case will raise awareness of the difficulties disabled people face doing everyday things, such as catching a bus.

\footnotetext{
${ }^{47}$ C Casserley, 'Disability, sight impairment, and the law', British Journal of Ophthalmology [2006] Oct 90(10) 1220-1222

${ }^{48}$ Irene Henrey, 'Access-ability' (2007) http://www.journalonline.co.uk/Magazine/52-3/1003965.aspx accessed 1 September 2017

49 ibid 47

50 David Brown, "'Wheelchairs v Buggies”: the Supreme Court ruling in FirstGroup v Paulley' (Bond Dickinson, 19 Jan 2017) https://www.bonddickinson.com/insights/publications-and-briefings/wheelchairs-v-buggiessupreme-court-ruling-firstgroup-v-paulley accessed 2 September 2017
} 
This on its own is a huge achievement for disabled people, especially in terms of creating easy access to employment.

According to the Labour Force Survey, disabled people are now more likely to be employed than they were in 2002 , but ... remain significantly less likely to be in employment than non-disabled people. In 2012, 46.3\% of working-age disabled people are in employment compared to $76.4 \%$ of working-age nondisabled people. ${ }^{51}$

Although disabled people are able to contribute positively to the country's economic development, they are not given a chance to do so, due to their disabilities. 'One of these [barriers] is the employers' perception of costs and benefits of accommodating and employing people with disabilities. ${ }^{52}$ However, this may be due to the fact that disabled people find it hard to access work for various reasons, 'such as lack of accessible transport or of supportive health and social care'. ${ }^{53}$ Service providers can help disabled people have easy access to work by making reasonable adjustments for them while they are using public transport. This may lead to an increase of disabled people in employment and, consequently, boost the country's economy.

\footnotetext{
${ }^{51}$ Official Statistics, Disability Facts and Figures (16 Jan 2014)

https://www.gov.uk/government/publications/disability-facts-and-figures/disability-facts-andfigures\#employment accessed $17^{\text {th }}$ August 2017

52 Why Is It Good For The Economy To Hire People With Disabilities? (23 June 2010) http://evengrounds.com/blog/why-is-it-good-for-economy-to-hire-people-with-disabilities accessed $17^{\text {th }}$ August 2017

${ }^{53}$ Department For Work and Pensions, 'Economic and social costs and benefits to employers of retaining, recruiting and employing disabled people and/or people with health conditions or an injury: A review of the evidence' (2006)

http://webarchive.nationalarchives.gov.uk/20130314011334/http://research.dwp.gov.uk/asd/asd5/rports200 5-2006/rrep400.pdf accessed $17^{\text {th }}$ August 2017
} 


\section{Conclusion}

In conclusion, it is submitted that the decision in Paulley v FirstGroup Plc ${ }^{54}$ has, indeed, restored faith in equality for disabled people, by clarifying the law and preventing an unlawful and unjustified discrimination from taking place. In particular, it has made it clear that bus drivers have a proactive responsibility to assist and safeguard people with disabilities. It has also helped raise awareness as to the extent of what a disabled person goes through to carry out a simple task, such as catching a bus. It is also clear that service providers should take some action to train their staff about what they can do when they are in such a situation.

Nonetheless, problems have been highlighted as to the practicality of a bus driver forcibly removing non-wheelchair users from the bus. How much force is reasonable? The decision has also had a huge impact on all public service providers, by putting pressure on them to take further training. This, however, can be seen to be quite impractical, time consuming and expensive. Surely if service providers have already been given the relevant training, it should be enough?

The case has also revealed that it is better to have a proactive approach than to wait for the problem to emerge and then tackle it. Furthermore, it is submitted that following this case, wider reviews should be carried out with regard to people with different types of disabilities, as well as disability in general. The fact that it takes a case to go to the Supreme Court for disability to be looked at more closely suggests that service providers, as well as the general public, are not doing enough to help disabled people carry out their daily activities.

\footnotetext{
${ }^{54}$ Paulley v FirstGroup plc [2017] UKSC 4 [2017] 1 WLR 423 (SC)
} 
Given the importance of this area and the fact that this case has occurred and occurs on a routine basis, perhaps some kind of updated guidance document should be made available to both service providers and disabled people. This does not have to be prescriptive, but it would help if it included realistic examples of issues that can occur and possible actions can be taken as a result.

In conclusion, it is expressed that the decision did not lead to a fair balance between disabled people and service providers. Should there be a similar case in the Supreme Court again, the court should take the opportunity to consider the legislation in this area. 


\section{References}

\section{$\underline{\text { Journal Articles }}$}

Practical Law Journal, 'Disability discrimination: Supreme Court considers reasonable adjustments under Equality Act 2010' IDS Emp L Brief 20171065 3-5

Public Law, ‘Discrimination' [2017] PL 2017 Apr 298-301

Keystone Law, 'Disability discrimination: reasonable adjustments' [2017] PLC 2017 28(2) 67-68

C Casserley, 'Disability, sight impairment, and the law', British Journal of Ophthalmology [2006] Oct 90(10) 1220-1222

Tabitha Collingbourne, "'The Care Act 2014: a missed opportunity?"' [2014] 20(3) Web JCLI

Brian Doyle, 'Disabled Workers' Rights, the Disability Discrimination Act and the UN Standard Rules' [1996] Ind Law J (1996) 25 (1) 1-14

Richard Griffith, 'Pushchairs can occupy wheelchair spaces on buses' British Journal of Midwifery [2015] 23 (2)

Sue Highmore, 'The Equality Act - its effect on property owners and tenants: Part 1' [2010] L \& T Review 2010 14(4) 134-137

Spencer Keen, 'Room to manoeuvre?' [2017] 167 NLJ 7734 p11

Phillip Leith, '"Merit, Speech Disability and Discrimination"' [2014] 20(3) Web JCLI

Jan Miller, 'Bus decision struck "balance”' [2017] 167 NLJ 7731 p5 (3)

Jan Miller, 'Rights on the buses' 164 NLJ 7634 p5 (1)

Nigel Powell, 'Challenging service providers to make reasonable adjustments' [2009] EOR 2009187 25-27

Jenny White, 'Disability discrimination and the travel industry: an outline of the law' [2004] ITLJ 20043 135-139

Peter JG Williams, Richard Waugh, 'On the wrong track' [2005] EG 20050517117

$\underline{\text { Reports and Guidance Papers }}$ 
Department For Work and Pensions, 'Economic and social costs and benefits to employers of retaining, recruiting and employing disabled people and/or people with health conditions or an injury: A review of the evidence' (2006) http://webarchive.nationalarchives.gov.uk/20130314011334/http://research.dwp.gov. uk/asd/asd5/rports2005-2006/rrep400.pdf accessed 17th August 2017

Papworth Trust, 'Disability in the United Kingdom 2014, Facts and figures' (2014) http://www.papworthtrust.org.uk/sites/default/files/UK\%20Disability\%20facts\%20and \%20figures\%20report\%202014.pdf accessed 23 March 2017

Steven Flynn, 'Supreme Court hands down judgment in "Wheelchair - v - Buggy" dispute' (2017) http://stjohnsbuildings.com/wp-content/uploads/Steven-FlynnComment-on-Paulley.pdf accessed 1 September 2017

$\underline{\text { Websites and Blogs }}$

Robin Allen and Catherine Casserley, 'Supreme Court hands down landmark disability decision in Paulley v FirstGroup plc' (Cloisters News, 18 Jan 2017) http://www.cloisters.com/latest/supreme-court-hands-down-landmark-decision-inpaulley-v-firstgroup-plc accessed 1 September 2017

David Brown, "'Wheelchairs v Buggies": the Supreme Court ruling in FirstGroup v Paulley' (Bond Dickinson, 19 Jan 2017)

https://www.bonddickinson.com/insights/publications-and-briefings/wheelchairs-vbuggies-supreme-court-ruling-firstgroup-v-paulley accessed 2 September 2017

Catherine Casserley and Jane Robertson, 'Paulley: An everyday step' (Cloisters, 30 Jan 2017) http://www.cloisters.com/blogs/paulley-an-everyday-step accessed 29 August 2017Equality and Human Rights Commission, 'Wheelchair spaces on buses must be a priority, court rules' Equality and Human Rights Commission (18 January 2017) https://www.equalityhumanrights.com/en/our-work/news/wheelchair-spacesbuses-must-be-priority-court-rules accessed 23 March 2017

Richard Hartley, 'Wheelchairs reign supreme in battle against prams (kind of)' Metro (18 January 2017) http://metro.co.uk/2017/01/18/battle-between-prams-andwheelchairs-on-buses-to-be-resolved-6387943/ accessed 18 January 2017 
Irene Henrey, 'Access-ability' (2007) http://www.journalonline.co.uk/Magazine/52-

3/1003965.aspx accessed 1 September 2017

Irene Henrey, 'Disabled from suing?' (2007)

http://www.journalonline.co.uk/Magazine/52-2/1003859.aspx accessed 30 August 2017

Anna Lawson, Catherine Casserly, 'First Group v Paulley: Towards Accessible and Inclusive Public Transport?' (Oxford Human Rights Hub, 3 March 2017) http://ohrh.law.ox.ac.uk/first-group-v-paulley-towards-accessible-and-inclusivepublic-transport// accessed 23 March 2017

Jodee Mayer, 'Is the judgment in Paulley v FirstGroup actually a victory for wheelchair users?' (Spinal Injury Blogs, 25 January 2017) http://www.boltburdonkemp.co.uk/news-blogs/spinal-injury-blogs/judgment-paulley-vfirstgroup-actually-victory-wheelchair-users/ accessed 25 March 2017

Official Statistics, Disability Facts and Figures (16 Jan 2014) https://www.gov.uk/government/publications/disability-facts-and-figures/disabilityfacts-and-figures\#employment accessed 17th August 2017

Paulley v First Group Plc, http://www.stammeringlaw.org.uk/cases/paulley.htm accessed 1 September 2017

Why Is It Good For The Economy To Hire People With Disabilities? (23 June 2010) http://evengrounds.com/blog/why-is-it-good-for-economy-to-hire-people-with-

disabilities accessed 17th August 2017

Newspaper Articles

'Making reasonable adjustments - and meeting particular needs' Ombudsman News (January/February 2015)

Marion Dakers, 'Stubbornly high personal injury claims set to push up cost of car insurance' The Telegraph (15 June 2015)

$\underline{\text { Statutes }}$

Equality Act 2010

$\underline{\text { Cases }}$ 
Aster Communities Ltd (formerly Flourish Homes Ltd) v Akerman-Livingstone (Equality and Human Rights Commission intervening) [2015] UKSC 15 [2015] AC 1399

Black v Arriva North East Ltd [2013] Eq LR 558 (CC)

Paulley v Firstgroup plc [2017] UKSC 4 [2017] 1 WLR 423 (SC) 